\title{
The Role of the Armed Forces of the United Kingdom in Securing the State Against Terrorism
}

\section{Jonathan Stevenson*}

The horror of the terrorist attacks of September 11, 2001 led to worldwide condemnation. All parts of the world mourned the victims of the attacks with a sense of shared loss that was heightened by the fact that many of the victims were of nationalities other than American. Allies rushed to the support of the United States, and NATO promptly declared that the attack on the U.S. could be considered an attack on the entire nineteen-nation alliance. But while the U.S. chose to hike defense spending and intensify its efforts on homeland security, the effect on European countries was somewhat different. The terrorist attacks constituted a watershed in threat perceptions in the U.S., but to a large number of European countries the threat seemed less novel.

Terrorist activities within national borders are not new to many states in Europe. Indeed, the continent's history is scarred by a relatively large number of terrorist activities and groups, including the Provisional Irish Republican Army (IRA), the Basque separatist organization Euskadi ta Askatasuna (ETA), the Greek far-left group November 17 Organization, the Red Army Faction in Germany, and the Red Brigades in Italy, to name but a few. Europeans did recognize that the "new terrorists"- that is, transnational Islamist terrorists - posed the threat of mass casualties, and were generally uninterested in bargaining or other modes of formal conflict resolution. But European governments also had more experience than the U.S. with terrorism, and they tended to see the new terrorism more as a continuation of old forms of terrorism than did the U.S. At least initially, for instance, European officials were less inclined to think that terrorists would use weapons of mass destruction (WMD).

Furthermore, the U.S. was perceived - justifiably - as the prime target of Al Qaeda and the transnational Islamist terrorist movement over which it loosely presides. Therefore, threat perceptions did not change as dramatically in Europe, and the sense of an urgent need to boost homeland security was not as strong as that prevailing in the United States. For most European governments, existing counter-terrorism measures were seen as basically adequate, although some adjustments were made to deal with the perceived threat of terrorism from WMD. Yet because the proportion of Muslims in European populations - especially in France, Germany, and the United Kingdomis far higher than it is in the U.S., and Muslim populations are generally less integrated, the challenges in terms of technical counter-terrorism (intelligence collection through surveillance and penetration, pursuit by police and/or special operations forces) in Europe are in some ways greater than they are in the U.S. However, falling military

Jonathan Stevenson is a Senior Fellow for Counter-terrorism at the International Institute for Strategic Studies in London. 
spending across Europe put a damper on any push to expand most homeland defense programs or jumpstart new initiatives. ${ }^{1}$

The United Kingdom, perhaps due to its singularly close strategic alignment with the United States, constitutes the starkest European exception to this trend. In the U.K., there is no statutory constraint comparable to the United States' Posse Comitatus Act, which, though the pressures of the global war on terror may be marginally eroding some of the Act's restrictions, substantially bars U.S. military operations on U.S. soil and against American citizens. Centuries of European political instability and warfare, two world wars centered in Europe in the twentieth century, and a persistent low-intensity guerrilla insurgency waged by the IRA in Northern Ireland since 1969 have resulted in a substantial role for the U.K.'s military forces in protecting British national territory. The rising threat from Al Qaeda and its affiliates and sympathizers indicated by the attacks of September 11 have prompted the British government to extend the territorial mandate of British armed forces in areas related to homeland defense. Especially in light of the previous demand for military action in protecting both infrastructure and the general population against IRA attacks on the British "mainland" (that is, England, Scotland, and Wales) as well as Northern Ireland itself, the post-9/11 enhancement of the military's mandate on British soil should be considered evolutionary rather than revolutionary.

\section{Historical Perspective}

\section{The Cold War Era}

During the Cold War, the U.K. military was focused primarily on the defense of Europe (mainly through NATO) against a Soviet ground invasion across Europe's central front. The military defense of the homeland against an advancing Warsaw Pact was, in that context, a subsidiary concern. There was, however, a significant additional role for the military in homeland defense in countering the IRA's terrorist insurgency in both Northern Ireland, where it originated as a means of forcing the British government to permit the province to unite with the Republic of Ireland, and the British mainland. From 1969, when the Northern Irish "troubles" became a full-blown insurgency, until 1976, the British Army had the lead responsibility for quelling IRA violence and pacifying Northern Ireland. In 1976, however, the British government sought to "criminalize" Northern Irish terrorism and "normalize" law enforcement in the province to the greatest extent possible by according primary authority to the Northern Irish police force, then known as the Royal Ulster Constabulary (RUC). The army continued to play an important support role, however. British soldiers routinely patrolled the streets of Belfast, Londonderry, and other locales in the province in armored vehicles, and participated in joint armed foot patrols with the RUC. The Special Air Service (SAS) also ran covert operations against the IRA, and the British Army main-

1 In general, see Jonathan Stevenson, "How Europe and America Defend Themselves," Foreign Affairs 82:2 (March/April 2003): 75-90. 
tained a garrisoned presence in Northern Ireland of between 20,000 and 30,000 troops between 1976 and 1994.

Beyond prosecuting counter-insurgency and securing airspace and surrounding waters, British policy did not contemplate a wholesale role for the military in homeland security, except at the request of debilitated civil authorities in the event of a strike by nuclear weapons or other WMD. As in the United States, however, the notion that civil defense could be effective against such devastation met with popular and, to a lesser extent, official skepticism.

\section{After the Cold War}

While the standoff between the Soviet Union and the West was ongoing, Northern Ireland remained a potentially important source of military-industrial capacity (missiles and shipbuilding) for the U.K. Furthermore, the U.K. might find tactical use for Northern Irish port facilities and military bases in any North Atlantic strategic confrontation, and therefore had an interest in keeping Northern Irish territory from becoming part of the Irish Republic, which was politically neutral. But as the Cold War drew to a close in the early 1990s, the British government acknowledged that Northern Ireland was no longer of intrinsic economic or strategic value to the Crown, and quietly but clearly promoted dialogue on the question of the province's sovereign status between the proBritish and mainly Protestant "unionist" majority there and the largely Catholic "nationalist" minority that favored Irish unification, including the IRA and its legal political wing, Sinn Fein. The IRA declared a unilateral cease-fire in August 1994, and six weeks later the pro-British "loyalist" paramilitaries followed suit. The political culmination of these developments was the Belfast Agreement of 1998 (also known as the Good Friday Accord). While there have been numerous violations of the cease-fires, and the implementation of the Belfast Agreement remains stalled, the cease-fires and political advances have resulted in a most likely permanent reduction in the level of terrorist violence. As a consequence, the military's role in domestic counter-insurgency has become residual and secondary; only about 10,000 troops are presently deployed in Northern Ireland.

More broadly, in the post-Cold War world, U.K. military planners saw the prospect of strategic attack on the British homeland as remote, perhaps even negligible. After the Soviet threat evaporated, no other power was regarded as having a ballistic missile force capable of threatening British soil. Contingencies in distant locations such as Bosnia and Sierra Leone suggested that expeditionary and force-protection capabilities - not homeland defense - should constitute the main U.K. military priorities. U.K. Foreign Minister Robin Cook commented in 1998 that, "in the post-Cold War world, we must be prepared to go to the crisis, rather than have the crisis come to us."2 While this sentiment accurately reflects some current Western strategic inclinations towards pre-emption and prevention, it also downplays the military's role in securing the

2 Quoted in House of Commons Defense Committee, A New Chapter to the Strategic Defense Review, Second Report, December 2001, para. 116. 
homeland. By the millennium, the U.K. appeared poised to become a substantially demilitarized homeland.

After 9/11

As indicated above, the 9/11 attacks drove home to the British government the point that the military could be required to support the civil authorities in the event of a mass-casualty terrorist attack. Yet, although the strongest British precedent for heavy military involvement in homeland security was counter-insurgency in the Northern Irish conflict, the emergent need for such involvement was mainly in the areas of infrastructure protection, first response, and civil defense. In February 2003, the British Army was called upon to ring Heathrow Airport on the basis of current intelligence that Islamist terrorists could be planning a surface-to-air missile attack on a jetliner. In September 2003, British authorities simulated a chemical attack on a subway station in downtown London to test (and demonstrate) government response capacities. Although government policy does contemplate military assistance to civilian authorities if necessary in the event of a chemical, biological, radiological, or nuclear (CBRN) attack, the military was not involved in this exercise. Its non-participation could support the House of Commons Defense Committee's conclusion at the end of 2001 that the circumstances in which the Ministry of Defense expected to call out units of the reserve forces - particularly the Territorial Army (TA) - in conditions short of general war were too limited, and that a more proactive role resembling that of the U.S. National Guard should be explored.

\section{Legal Authority}

The U.K. has no hard-and-fast statutory bar to the application of military resources to domestic threats comparable to the United States' Posse Comitatus Act. ${ }^{3}$ Nevertheless, longstanding political and legal custom and common law circumscribe such application. The Ministry of Defense considers the principle that military support for domestic civilian authorities must be provided at their specific request in order to be effectively "constitutional." This view was reinforced in discussions of the then-prospective new Strategic Defense Review chapter in the House of Commons in December 2001, when British Defense Doctrine was quoted as follows:

3 The Posse Comitatus Act is found at 18 U.S.C., Section 1385, which bars the use of the military in activities customarily reserved for law enforcement, such as arrest, seizure of evidence, searches of buildings, interrogating witnesses, pursuing escaped prisoners, and searching for suspects. However, "passive" assistance such as logistical support, technical advice, use of facilities, and training is not prohibited. Nor is technical support like explosive ordnance disposal or advice and assistance with respect to WMD. See, e.g., Jeffrey D. Brake, "Terrorism and the Military's Role in Domestic Crisis Management: Background and Issues for Congress," CRS Report for Congress (Washington, D.C.: Congressional Research Service, 19 April 2001), 12.

4 “The Strategic Defence Review: A New Chapter,” Public Discussion Paper, 6. 
[T] he use of the Armed Forces for domestic purposes is potentially controversial, and strict limitations are placed on their domestic employment. The relationship between the Armed Forces and civil authorities in the U.K. is the subject of aspects of constitutional and administrative law and there has developed, over three hundred years, a legal doctrine governing the domestic use of military personnel. At the core of that doctrine is the absolute primacy of civil authorities; when Armed Forces personnel are used on domestic tasks they are only employed in support of relevant and legally responsible civil authorities. ${ }^{5}$

Even in a state of emergency, then, the British military has no primary or independent authority on British soil absent a complete breakdown of civil authority and at least an implicit delegation of that authority to the military.

\section{Types and Availability of Forces}

On 31 October 2002, the Minister for the Armed Forces announced that an enhanced domestic military reserve capability would take the form of fourteen Civil Contingency Reaction Forces (CCRFs) - one for each of the army brigade regions in the U.K., each composed of 500 volunteers. Some 7,000 volunteers will make up the CCRFs. The Territorial Army is the U.K.'s largest reserve body, with a strength of 40,350 troops. The TA comprises fifteen infantry, four light reconnaissance, and two special-forces battalions, as well as five engineering, four air-defense, and three artillery regiments, and one aviation regiment. Home service forces also include 3,390 troops (2,100 fulltime) recruited in Northern Ireland. As of October 2004, some 10,700 regular armedforces personnel—overwhelmingly from the British Army — were deployed in Northern Ireland for residual counter-insurgency and counter-terrorist operations. ${ }^{6}$ British military doctrine, of course, also contemplates the use of regular armed forces in homeland emergencies.

\section{Protection of Critical Infrastructure}

Owing to the entrenched support role of the British military in homeland security, efforts in critical infrastructure protection-including information technology, nuclear facilities, power generation capacity, communications networks, civilian government installations, and industrial capacity - remain primarily the responsibility of civilian authorities and private owners. They are advised by the Security Service (also known as MI5), which is the UK's domestic intelligence agency, and wholly civilian in nature. Nevertheless, since $9 / 11$, the role of the military in infrastructure protection, while still extraordinary, has become considerably more salient.

Indeed, that role became conspicuous in February 2003, when over 1,000 soldiers (initially 450) were deployed for over a week in West London to help police protect Heathrow International Airport on the strength of a civilian intelligence assessment that

5 U.K. Ministry of Defence, British Defence Doctrine ( $2^{\text {nd }}$ edition, October 2001), 6-9.

6 Figures are from International Institute for Strategic Studies, The Military Balance 2004/2005 (Oxford: Oxford University Press for the IISS, 2004), 73, 75. 
commercial passenger airliners could be the targets of terrorist surface-to-air missile attacks. The soldiers were armed with automatic weapons. Some patrolled the airport on foot, while others assisted local police in stopping vehicles on roads underneath Heathrow's flight path at checkpoints set up inside an eight-mile radius of the airport. Others monitored the airport perimeter in armored reconnaissance vehicles (mainly 8.7-ton Scimitars, equipped with $30-\mathrm{mm}$ cannon and 7.62- $\mathrm{mm}$ machine-guns, with a top speed of fifty miles per hour). The soldiers were drawn from the $1^{\text {st }}$ Battalion of the elite Grenadier Guards, as well as the Household Cavalry. While the army was enlisted through designated official channels, specifically at the request of the police, the Heathrow operation was the first time that the military had been involved in securing the airport since 1994, when the IRA launched mortar rounds at Heathrow.

Some skeptical observers apprehended the Heathrow operation as a kind of publicity stunt, designed to condition the public for more draconian security measures in other realms of life. One British Muslim, for instance, remarked: "I think probably the authorities feel that they should build up emotions - what I call the "war spirit.",7 The overall danger of surface-to-air missiles, however, was credible. Two had been launched at an Israeli jetliner leaving Mombasa, Kenya, in November 2002, narrowly missing the plane, and tens of thousands of the hand-held missiles were in illicit - or at least unregulated - circulation. In any case, the operation demonstrated that, after 9/11, a lower threshold of intelligence warning would trigger military support for civilian authorities generally, since the consequences of the kind of mass-casualty attack preferred by the "new" transnational Islamist terrorists superseded its probability from the standpoint of prevention.

Andrew Marr, a thoughtful British Broadcasting Corporation journalist, noted the "appalling dilemma" faced by ministers who had to implement effective day-to-day domestic security operations when faced with a mountain of intelligence to analyze as well as "a political blame culture and an unquantifiable threat." ${ }^{\text {In }}$ the U.K., such officials are now more likely to call on the military to support civilian authorities. Yet they have done so sparingly since February 2003 - probably, at least in part, as a result of the criticisms that the Heathrow operation elicited. Indeed, in June 2002, Assistant Metropolitan Police Commissioner David Veness testified in Parliament to the Select Defense Committee that, while the military could be useful in certain limited domestic contexts, the U.K. had no "gendarmerie," no "third force," and no "national guard." Thus, he continued, if faced with "a threat that required [civil authorities] to protect a sector of British industry which is pretty geographically spread"-and therefore beyond regular police capacities - the first resort would be to the special constabulary, and the second to the private security industry. The fact that the military was not in his

7 "Blair Authorised Terror Alert Troops," BBC News, 17 February 2003; available at: news.bbc.co.uk/1/hi/uk/2747677.stm.

8 "Ministers Highlight UK Terror Threat," BBC News, 14 February 2003; available at news.bbc.co.uk/1/hi/uk/2751361.stm. 
"batting order" is a telling indication of the reluctance of civilian officials in the U.K. to call on the military for support. ${ }^{9}$

\section{Border and Transportation Security}

Except for operating armed checkpoints on the border between Northern Ireland and the Irish Republic, the fact that mainland Britain is an island has resulted in little direct military involvement in territorial border security. The key agencies in border control-the police (including Special Branch and a National Coordinator for Ports Policing), the Security Service (i.e., MI5), and Immigration and Customs - are all civilian, and the approach is intelligence-driven. Should terrorists breach border security, however, there is a paramount role for the military-especially special operations forces - in search operations, a role that is duly acknowledged by law-enforcement professionals to require skills "beyond that which can be provided by any U.K. police force." 10 The skills of the SAS, for instance, have been famously (to some, infamously) employed against the IRA in Northern Ireland and on other British soil, notably Gibraltar.

Similarly, transportation security in the United Kingdom has been largely a matter for the civil police authorities. In general, the British government has a great deal of confidence in its civilian transportation security apparatus - mainly, the Transportation Security Directorate of the Department of Transport — which was reinforced following the destruction of Pan Am Flight 103 over Lockerbie, Scotland by a terrorist bomb in 1989. In particular, British law-enforcement officials place great stock in the extensive closed-circuit television (CCTV) camera surveillance systems now in place in transportation venues. ${ }^{11}$ Nevertheless, the specific prospect of a sea-based attack on the U.K. has raised government awareness of a potential need for maritime military assistance in securing the homeland. For example, in December 2001 the British Royal Marines were dispatched to board a merchant vessel suspected of carrying terrorist materials - possibly materials required for producing WMD — or perhaps even being itself the vehicle for a coastal attack. This operation required close cooperation and coordination among intelligence services, customs officials, police, and the military, and has led to enhanced standing lines of communication and regular procedures among these four groups. And of course, the Heathrow operation was, from one perspective, a special instance of transportation security.

\section{Domestic Counter-terrorism}

At the request (usually) of the relevant police chief - through the Home Office, and then by formal agreement with the Ministry of Defense - the U.K. military can provide

\footnotetext{
9 See, e.g., United Kingdom Parliament, Select Committee on Defense, Examination of Assistant Commissioner David Veness, CBE, and Deputy Chief Constable Alan Goldsmith, 7 May 2002.

10 Ibid.

11 Ibid.
} 
specialized military aid to the civil power (MACP) in the form of bomb disposal and other specialized equipment and expertise. In most cases, the police request would be very specific and circumscribed. In extraordinary circumstances, though, if the police demonstrate the need, the Home Office can agree to general military support. This occurred when the army was deployed around Heathrow Airport in early 2003 to guard against surface-to-air missile attacks. Even then, however, the police operational commander determined jointly with the military commander what, where, and how the military equipment and personnel would be deployed.

As discussed above, except for the first four or five years of the Northern Irish conflict, during which the situation in the province sometimes verged on civil war, the armed forces have officially played a police support role in countering domestic terrorism, which the British government has approached as an essentially criminal problem since 1976. The reality is more nuanced, however, as Irish republican insurgents have killed more than twice as many soldiers than police. In addition to supporting the RUC, the army has played an important role in the area of intelligence in Northern Ireland. Nevertheless, MI5 - the UK's domestic intelligence agency-has been the lead agency in a central body for collating and coordinating intelligence from all relevant sources, including the Royal Ulster Constabulary's Special Branch, its Scotland Yard counterpart, as well as army intelligence. From that position, MI5 has exercised control over intelligence-driven counter-terrorist operations. This special arrangement, however, effectively accorded MI5 a key role in overseeing law-enforcement - the execution of which remained the RUC's responsibility - by lowering the institutional barriers between intelligence collection and law enforcement. Perforce, army intelligence played a role in domestic counter-terrorism. But it is unlikely that the level of input reached during the Northern Irish "troubles" has been sustained as they have wound down over the past decade.

\section{Catastrophic Terrorist Attacks: First Response and Consequence Management}

The general implication of the more particular doctrinal and legal limitations on the U.K. military's role in securing the British homeland is that the military is most likely to be summoned by civilian authorities in the case of a catastrophic terrorist attack for which their response and consequence management capabilities are inadequate. Relatively unspectacular tasks unrelated to terrorism for which the British armed forces were rallied to offset such incapacity include the control of traffic during a fuel strike in summer 2000, the disposal of livestock affected with foot-and-mouth disease in 2001 , and the provision of firefighting services during a national firefighters strike in 2003. In the event of a mass-casualty terrorist attack, there would appear little doubt that the military would be called on for assistance in some capacity. The possible tasks specifically enumerated by the Ministry of Defense for the CCRFs, for example, include cordoning, evacuation, provision of temporary lodging and feeding facilities, and logistical support: all paramount needs in the event of most conceivable catastrophic attacks. 


\section{Current Formal National Policy}

The British government's philosophy of civil contingency planning is based on the concept of resilience, which is defined as the ability "at every relevant level to detect, prevent, and, if necessary, to handle and recover from disruptive challenges." fundamental to this concept that domestic emergencies are in the first instance to be handled at the local level. If local capacity is insufficient, the next resort is to neighboring jurisdictions. Only when such mutual local- and regional-level assistance is unavailing does the central government become involved through a lead government department; which department takes the lead varies depending on the nature of the emergency. That department is then required to alert the Civil Contingencies Secretariat (CCS) in the Cabinet Office.

The CCS in turn assesses the whole situation and determines which resources (potentially including military ones) need to be marshaled. The CCS, through the Civil Contingencies Committee (CCC), "is to provide the central focus for the cross-departmental and cross-agency commitment, coordination and cooperation that will enable the U.K. to deal effectively with disruptive challenges and crises." ${ }^{13}$ In particular, the CCC will determine whether overall strategic (as opposed to tactical or operational) responsibility for dealing with the contingency in question should be delegated to one of several devolved administrations or assumed by a central authority.

Combined response - with an emphasis on multi-agency command, control, and coordination - remains key to the British approach to homeland security. The CCS specifically contemplates the "armed forces" as well as emergency services, local authorities, central government, the health service, and the voluntary sector as potential elements of a combined effort. ${ }^{14}$ In turn, British military doctrine establishes a relatively muscular (but still strictly secondary) role for the armed forces in securing the British homeland. The U.K.'s military doctrine considers maintaining the freedom and territorial integrity of the United Kingdom as chief among the goals of British security policy. This goal expressly includes "sustaining the rule of law and internal order within the United Kingdom." "British military doctrine also specifies, as one of three overlapping defense roles, ensuring the protection and security of the United Kingdom "even when there is no external threat." 16 Thus, the potential scope for the military's role in securing the British homeland is doctrinally broad. Indeed, the very first of the seven mission types for the military officially enumerated is "military aid to the civil

12 Civil Contingencies Secretariat, Dealing with Disaster (revised $3^{\text {rd }}$ edition), Chapter 7; available at www.ukresilience.info/contingencies/dwd/c1 introduction.htm. Ibid., Chapter 7, www.ukresilience.info/contingencies/dwd/c7central.htm.

14 Ibid.

15 Design for Military Operations - The British Military Doctrine, Prepared Under the Direction of the Chief of the General Staff, Army Code 71451, (1996), 1.

16 Ibid., 2. 
power in the United Kingdom." ${ }^{17}$ In turn, British doctrine enunciates three forms of military aid to civil authorities:

- Military aid to the civil community (MACC). MACC is the provision of military personnel and equipment in both emergencies (e.g., natural disasters) and in routine situations to assist the community at large;

- Military aid to civil ministries (MACM). MACM is the use of military forces for non-military government tasks, including ensuring the essential safety of members of the community and undertaking matters of national importance;

- Military aid to the civil power (MACP). MACP provides for the direct maintenance or restoration of law and order in situations beyond the capacity of the civil power to resolve using any other resources. The rule of thumb for the military is to respond to a civilian request for assistance, resolve the immediate problem, and return control to the civil power as expeditiously as possible. ${ }^{18}$

Indeed, MACP has been provided continuously to combat the IRA's terrorist insurgency campaign since 1969. This long involvement in counter-insurgency and counterterrorism on U.K. soil gave the British military arguably unique, and certainly extraordinary, experience in thwarting asymmetric threats. The U.K. military has also recently assisted civil authorities in dealing with fuel strikes, floods, and the foot-and-mouth epidemic, as well as filling in for striking firefighters.

London, like other European capitals, had underestimated the threat posed by $\mathrm{Al}$ Qaeda. The U.K. did begin to wake up before 9/11, outlawing twenty-one terrorist front organizations - sixteen of them Islamist in nature - early in 2001. But Britain has remained a key indoctrination, staging, and logistics center for $\mathrm{Al}$ Qaeda members. In December 2001, the U.K. parliament responded decisively to the increased terrorist threats revealed by $9 / 11$, passing laws comparable in effect to the USA PATRIOT Act. These included requirements that communications companies retain accessible records of calls made and e-mails sent (though not their contents), more rigorous record-keeping requirements for transport companies, enhanced financial surveillance and restriction authorization, provisions for greater inter-agency exchanges of intelligence, and a controversial power of indefinite detention applicable to suspected international terrorists. In June 2002, a security and intelligence coordinator was appointed at permanent-secretary rank. It is noteworthy, however, that none of these admittedly muscular provisions involved the British military.

Furthermore, in practice, the British military was unprepared for the extreme and novel demands that apocalyptic terrorism of the $9 / 11$ variety-which differs plainly from the IRA's relatively restrained use of political violence - could place on the military in the domestic context. The U.K. Ministry of Defense's Strategic Defense Review (SDR), completed in 1998, emphasized primarily improvements in conventional warfighting capabilities - that is, in reconnaissance, surveillance, rapid deploy-

17 Ibid., 3.

18 Ibid., 5. 
ment, target acquisition, precision-strike capability, and command-and-control. The SDR did not account for the increasing possibility that discontented nations and nonstate groups would refuse to meet in the U.K. military's preferred and contemplated theatre of action. In a 2002 Public Discussion Paper calling for a new chapter in the SDR to deal with the threat of apocalyptic terror, the Ministry of Defense itself noted:

The SDR admitted the potential existence of asymmetric threats, but it is fair to say that it did not treat such threats as a strategic risk, but more as one of a range of tactics that an adversary might use. It was the emergence of asymmetric action as having the potential for strategic change that has prompted the work we are now undertaking. ${ }^{19}$

Included in the ministry's prospectus for the content of the new chapter of the SDR was "the contribution that the Armed Forces make to protecting the U.K. itself." 20

While the U.K. Home Office has primary responsibility for counter-terrorism on British soil, the military has always provided for the overarching physical defense of the realm in guarding airspace and territorial waters. After 9/11, RAF fighters were placed on heightened alert, and have been scrambled to monitor suspect aircraft several times. The Ministry of Defense observed that the American experience on and after 9/11 demonstrated that transnational terrorism implicated these homeland-defense functions, and that they required some rethinking, particularly as to the operational tempo and the speed of decision-making. Also inferred from the aftermath of the 9/11 attacks in the U.S. was the need for closer coordination between civilian and military authorities "in order to maximize the utility and suitability of responses to any future requests [by the civilian authorities for military assistance] at the national, regional, and local levels. $" 21$

In the Report of the House of Commons Defense Committee on the new chapter, published in May 2003, the committee concluded that, while the events of September 11 had raised the priority of homeland defense in the British military's thinking, the new chapter contemplated not a greater role for the armed forces in assisting civil authorities, but rather a greater role for the reserves. ${ }^{22}$ As noted, the enhanced domestic military reserve capability would take the form of fourteen CCRFs: one for each of the army brigade regions in the U.K., each made up of 500 volunteers. Thus, the CCRFs' total strength would be about 7,000 troops. (By comparison, France's Directorate of Territorial Security has about 1,500 employees.) Along with the CCRFs, the Ministry of Defense has established an enhanced regionally-based planning and command capability which is intended to facilitate rapid support from the armed forces (both regular and reserve) to civil authorities, as well as an integrated communications structure to

19 UK Ministry of Defense, The Strategic Defense Review: A New Chapter, Public Discussion Paper (February 2002), 3.

20 Ibid., 4.

${ }^{21}$ Ibid., 6.

${ }^{22}$ House of Commons Defense Committee, A New Chapter to the Strategic Defense Review, Sixth Report of Session 2002-2003, 26. 
be provided by a Territorial Army (TA) formation and two signal brigades. In total, the reserve forces were to receive 700 new posts and an additional 130,000 man-training days. The CCRFs do not encompass or overlap with the TA, the U.K.'s main reserve force, though they would be mobilized through TA centers. Start-up costs for the CCRFs were estimated at $£ 2$ million, the annual cost of the CCRF scheme at $£ 4.5$ million, and costs over four years in the civil contingencies arena at $£ 60$ million. ${ }^{23}$ The CCRFs were to have achieved full operating capability by 31 December 2003 . The CCRFs would be used mainly for civil support in the aftermath of a major disaster, the consequences of which were beyond the capabilities of civil authorities. Likely tasks include cordon and evacuation, providing temporary accommodation and feeding facilities, and general logistical support.

It is worth noting, however, that the CCRFs' utility was contemplated only at the margins; the Defense Committee hastened to add that, in a serious terrorist contingency on British soil, regular army units would probably still be preferred for their superior training and experience, and that the CCRFs were intended merely to give British commanders an additional source of manpower. Accordingly, the Committee concluded:

Overall, we have seen little evidence that the Ministry of Defense has taken seriously the need to rethink the capacity of the Armed Forces to provide predictable support to the task of home defense in the event of a mass-effect terrorist attack in the U.K. ${ }^{24}$

Indeed, there appears to have been little articulation of British military or defense doctrine around a number of security challenges that have increased in salience since September 2001-for example, airline hijacking and hostage-taking, both of which could well occur on U.K. soil.

\section{Conclusion}

Since the September 11 attacks, the role of the U.K. military forces in securing the British homeland has increased only incrementally. The primary reason for the merely marginal enhancement of that role is the U.K.'s well-established principle that civilian authorities should manage crises to the maximum practicable extent in a mature democracy. The consensus among U.K. officials is that this principle remains valid. At the same time, the extraordinary and largely uncharted character of the global jihadist threat has prompted some to question the government's conservatism in this area. To be sure, since 9/11 the British government has emphasized civil defense and national resilience, having simulated a chemical attack in central London to sharpen its preparedness. In light of transnational Islamist terrorists' preference for mass casualties, British law-enforcement agencies are more inclined than they were when the IRA was the main terrorist adversary to arrest suspects preventively. Since the Madrid bombings

23 Ibid., 27.
24 Ibid., 30. 
in March 2004, British civil authorities have reiterated that a terrorist attack in the U.K. is "inevitable."

The British are probably as ready to deal with such an attack as any jurisdiction in Europe. Yet local and regional officials, through the Emergency Planning Society, have criticized the U.K.'s level of civil-defense preparedness, noting that its first responders could handle a limited IRA-style operation but not a no-warning mass-casualty attack on the order of the Madrid bombings. Although the U.K.'s civil-defense budget has increased by 35 percent over pre-2001 levels, it is still only $£ 35$ million per year, and the government faces a considerable challenge in rebuilding a system that was dismantled in 1991-92 after the Cold War ended. Even when it was intact, with a network of regional headquarters, the system's response time was measured in days. It would be difficult, and perhaps impossible, to deploy comprehensive preventive means to compensate for any first-response deficiencies. For instance, the U.K.'s 11,000-mile, 2,500-station rail network, which is used by five million people a day, is extremely vulnerable. Metal detectors and baggage scanners are used only on the Eurostar service running between London and Brussels and London and Paris. Universal airport-style security checks would be impractical and prohibitively expensive.

Thus, there are strong arguments for making the military's contemplated involvement in U.K. homeland security efforts more substantial. These may prompt greater activity in training and equipping regular army units as well as the CCRFs and the TA to assist civilian authorities, particularly in the event of a CBRN attack. Given the UK government's longstanding - and, indeed, supportable - philosophical bias in favor of civil domestic control, however, it is likely to respond to these arguments mainly by enhancing civilian capacity rather than doctrinally or operationally augmenting the military's role in homeland security. 
THE QUARTERLY JOURNAL

\section{Bibliography}

Brake, Jeffrey D.. Terrorism and the Military's Role in Domestic Crisis Management: Background and Issues for Congress In CRS Report for Congress. Washington, D.C.: Congressional Research Service, 2001.

Stevenson, Jonathan. "How Europe and America Defend Themselves." Foreign Affairs 82, no. 2 (2003): 75-90. 